\title{
OPTIMAL CONDITION FOR MULTIPLEX POLYMERASE CHAIN REACTION (PCR) IN DETECTING ASCARIS LUMBRICOIDES, TRICHURIS TRICHIURA, AND NECATOR AMERICANUS IN PRESERVED STOOL
}

Received: 12-03-2020。Accepted: 30-07-2020

http://dx.doi.org/10.21460/bikdw.v5i1.171

\begin{abstract}
Christiane Marlene Sooai ${ }^{1,2}$, Elsa Herdiana Murhandarwati ${ }^{1}$, Supargiyono $^{1}$
${ }^{1}$ Department of Parasitology, Faculty of Medicine, Public Health and Nursing, Gadjah Mada University, Yogyakarta

${ }^{2}$ Faculty of Medicine, Universitas Kristen Duta Wacana, Yogyakarta

Correspondence: marlenesooai@gmail.com
\end{abstract}

\begin{abstract}
Background: Multiplex PCR examination is one of the molecular examination methodologies applied to detect soil-transmitted helminth (STH) infection. Optimization of the multiplex PCR method is a complex process, but it is necessary to obtain both a correct detection process and a satisfactory DNA product.

Objective: To determine whether multiplex PCR can be optimized to diagnose STH from Indonesian isolates, and to find the optimal method for detection of $A$. lumbricoides, T. trichiura, and $N$. americanus infections in stool that have been stored for 3 years.

Methods: A total of 15 samples were examined, and these samples were previously examined by using a microscopic method, then continued with optimization steps. Result: The optimal PCR mixture used primers targeting COI gene for $A$. lumbricoides, $18 \mathrm{~S}$ rDNA for $T$. trichiura and ITS 1 for $N$. americanus, $15 \mu \mathrm{l}$ of Go Taq Green Master Mix, $5 \mu \mathrm{l}$ of the 3 pairs of primers, $5 \mu \mathrm{l}$ of DNA template and $4 \mu \mathrm{l}$ of $\mathrm{DdH} 2 \mathrm{O}$, and the condition was 30 minutes of $95^{\circ} \mathrm{C}$ denaturation, 30 second of $53^{\circ} \mathrm{C}$ annealing and 1 minute of $72^{\circ} \mathrm{C}$ extension, repeated for 35 cycles.

Conclusion: Multiplex PCR can be optimized for STH detection from Indonesian isolates. The successful detection using the multiplex PCR method was influenced by sample preparation prior to DNA isolation, which includes several steps i.e. homogenization of samples using bead beaters and passing samples on liquid nitrogen rapidly.
\end{abstract}

Keywords: multiplex polymerase chain reaction, ascaris lumbricoides, trichuris, necator americanus 


\section{INTRODUCTION}

Soil-transmitted helminth (STH) infection has a worldwide distribution. In 2017, the World Health Organization estimated about $24 \%$ of the world population had infected with STH, especially Ascaris lumbricoides, Trichuris trichiura, Necator americanus, and Ancylostoma duodenale. ${ }^{1}$ In Asia, the prevalence of STH infection reached $73 \%$, where India and China with the highest proportion. ${ }^{2}$ The prevalence of helminthiasis in Indonesia in 2015 varied by region, ranging from 20 to $86 \%$, with an average of $30 \% .^{3}$

The diagnosis of STH infection is generally conducted by using microscopic and molecular approaches. The later include Polymerase Chain Reaction (PCR), quantitative PCR (qPCR), and multiplex PCR. The PCR method has high sensitivity in detecting parasitic deoxyribonucleic acid (DNA). ${ }^{4}$ In the past decades, multiplex PCR has been used for parasitology evaluation, due to its time efficiency, accuracy and its ability to detect co-infections. These features support an effective diagnosis for daily clinical practice and public health measures.5,6 However, some PCR test cycles might not yield valid results. The multiplex PCR process is influenced by several factors, such as DNA concentration and quality, annealing temperature, $\mathrm{MgCl}_{2} \quad$ concentration, primer concentration and quality, number of PCR cycles, the concentration of dNTP and other supporting materials. 7,8

Previous studies have been conducted to determine the optimal condition to produce reliable results, yet there were only a few studies that exercise this optimisation on Indonesian samples. This research is aimed to determine the optimal condition for the identification of $A$. lumbricoides, $T$. trichiura, and $N$. americanus DNA using multiplex PCR method on preserved stool samples.

\section{METHODS}

\section{Material}

All stool samples were acquired from the storage facility at the laboratory of parasitology, Faculty of Medicine, Public Health and Nursing, Universitas Gadjah Mada. The samples were preserved for three years in ethanol 96\%, at the temperature $-20^{\circ} \mathrm{C}$. There are 15 stool samples were obtained from infection cases (of A. Lumbricoides, T. Trichiura, and hookworm) in Maluku Province, Indonesia, in 2015.

Table 1. Primary nucleotide sequences A. lumbricoides, T. trichiura, and N.americanus used in multiplex PCR.9

\begin{tabular}{lccc}
\hline $\begin{array}{l}\text { Helminth spp/DNA } \\
\text { target }\end{array}$ & Forward primer, 5' $\rightarrow \mathbf{3}^{\prime}$ & $\begin{array}{c}\text { Nucleotide } \\
\text { length (nt) }\end{array}$ & $\begin{array}{c}\text { Product size } \\
\text { (Base pair) }\end{array}$ \\
\cline { 2 - 4 } A. lumbricoides/COI & $\begin{array}{l}\text { GGAGGTTTTTGGGTCTTTGG } \\
\text { CCAAACAAGGTAGCCAACCA }\end{array}$ & 20 & 192 \\
$\begin{array}{l}\text { T. trichiura/18S } \\
\text { rDNA }\end{array}$ & $\begin{array}{l}\text { CTGCGAGGATTGACAGATCA } \\
\text { GTACAAAGGGCAGGGACGTA }\end{array}$ & 20 & 498 \\
N. americanus/ITS1 & $\begin{array}{l}\text { ATGCTTGGCAAGAGTCGTTT } \\
\text { TGTTGGCGTCCACACATATT }\end{array}$ & 20 & 330 \\
\hline
\end{tabular}




\section{PCR Methods}

The diagnostic examination was conducted in several steps. First, the faecal specimens were prepared, either for microscopic stool examination and multiplex PCR testing. For the PCR testing, the faecal deposits were initially emulsified with Lugol solution and further washed with $300 \mu \mathrm{H}_{2} \mathrm{O}$. At the molecular processing stage, the resulted suspensions were centrifuged and further washed two times with the same amount of $\mathrm{H}_{2} \mathrm{O}$. Further PCR steps were performed with methods described by Phuphisut et al. 9

The second step is DNA isolation from the prepared specimens. All specimen underwent different treatment before DNA isolation procedure, which is (1) direct DNA isolation without pretreatment, (2) bead-beating homogenisation before DNA isolation (on selected samples), and (3) beadbeating homogenisation and liquid nitrogen treatment before DNA isolation. We used FavorPrep ${ }^{\mathrm{TM}}$ Stool DNA Isolation mini kit (Favorgen, Taiwan) for all specimen. The DNA isolation was performed with PCR components which include $15 \mu 1 \mathrm{PCR}$ mixture (GoTaq ${ }^{\circledR}$ Green Master Mix (Promega, USA)). $1 \mu 1$ primers of each parasite (forward and reverse), two concentration $(2 \mu 1$ or $5 \mu \mathrm{l})$ of DNA template, and $\mathrm{H}_{2} \mathrm{O}$ to adjust the total volume to $30 \mu 1$.

On the DNA amplification stage, we initially used a thermocycler with three steps, (1) denaturation at $95^{\circ} \mathrm{C}$ for 3 minutes; (2) annealing of primers (selected specimen underwent five different temperature, $50^{\circ} \mathrm{C}, 51^{\circ} \mathrm{C}, 52^{\circ} \mathrm{C}, 53^{\circ} \mathrm{C}, 54^{\circ} \mathrm{C}$ ) for 20 seconds; and extension at $72^{\circ} \mathrm{C}$ extension for 1 minute. We changed the extension time to 5 minutes in the last cycle. Further amplification was conducted with a DNA amplifier machine, using primers targeting A. lumbricoides, T. trichiura and $\mathrm{N}$. americanus DNA (Table 1).

Finally, the amplified specimens further underwent electrophoresis on $2 \%$ agarose gel, with $100 \mathrm{~V}$ voltage for approximately 30 minutes. The results were visualized through a transilluminator gel documentation machine.

Table 2. The result of a microscopic examination on the preserved stool specimens from Maluku Province, Indonesia ( $=15$ ).

\begin{tabular}{rrrc}
\hline \multirow{2}{*}{ ID } & \multicolumn{3}{c}{ Type of parasite } \\
\cline { 2 - 4 } & Ascaris lumbricoides & Trichuris trichiura & Hookworm \\
\hline 1 & Positive & Positive & Negative \\
2 & Positive & Positive & Negative \\
3 & Positive & Positive & Positive \\
4 & Positive & Positive & Negative \\
5 & Positive & Positive & Positive \\
6 & Positive & Positive & Positive \\
7 & Positive & Positive & Positive \\
8 & Negative & Positive & Negative \\
9 & Positive & Positive & Positive \\
10 & Positive & Positive & Negative \\
11 & Positive & Positive & Negative \\
12 & Positive & Positive & Negative \\
13 & Positive & Positive & Negative \\
14 & Positive & Positive & Positive \\
15 & Negative & Positive & Negative \\
\hline
\end{tabular}


To determine the optimal DNA concentration yielding the best result, we made several preparations with different DNA concentration from a selected specimen with triple infection, using dilution method (gradual addition of distilled $\mathrm{H}_{2} \mathrm{O}$, with equal volume). This dilution was stopped after the final electrophoresis did not produce positive bands anymore. We further measure the DNA concentration of each specimen with a nanodrop machine.

\section{RESULTS}

According to the microscopic examination, among 15 specimens, $A$. lumbricoides, T. trichiura, and $N$. americanus were detected in 13 $(86.7 \%), \quad 15(100 \%)$, and 6 (40\%) samples subsequently. Mixed infection with A. lumbricoides, T. trichiura were observed in 13 samples $(86.7 \%)$, and mixed infection with three parasites were observed in 6 samples (40\%). Table 2 describes the microscopic examination of each specimen.

\section{Optimal Annealing Temperature}

DNA isolation with five different annealing temperature $\left(50^{\circ} \mathrm{C}, 51^{\circ} \mathrm{C}\right.$, $52^{\circ} \mathrm{C}, 53^{\circ} \mathrm{C}, 54^{\circ} \mathrm{C}$ ) was performed on sample No. 3. Figure 1 shows the electrophoresis result of different annealing temperature, where lane 4 (annealing temperature $53^{\circ} \mathrm{C}$ ) yields the best result for multiplex PCR on a triple infection.

\section{Sample Weight And DNA Template Volume}

The sample weight in this study is 5 $\mathrm{mg}, 30 \mathrm{mg}, 50 \mathrm{mg}, 100 \mathrm{mg}$ and 200 $\mathrm{mg}$ and the templates volume are $2 \mu \mathrm{l}$ and $5 \mu$. Initial tests used $5 \mathrm{mg}$ sample and $2 \mu$ DNA template which detected 4 double infections (A. lumbricoides and $N$. americanus) and 4 single infections (one $A$. lumbricoides, one T. trichiura infection, and two $N$. americanus infections). There are four Necator involvements which did not show on microscopic examination (No. 4, 10, 13, and 15). Further combination of $30 \mathrm{mg}$ samples and $5 \mu \mathrm{l}$ DNA template could only detect 4 double infections (A. lumbricoides and $N$. americanus) and 5 single $A$. lumbricoides infections. The final combination used was $200 \mathrm{mg}$ sample and a $5 \mu \mathrm{l}$ DNA template. Combined with the pre-treatment, this combination yielded the best detection rate.

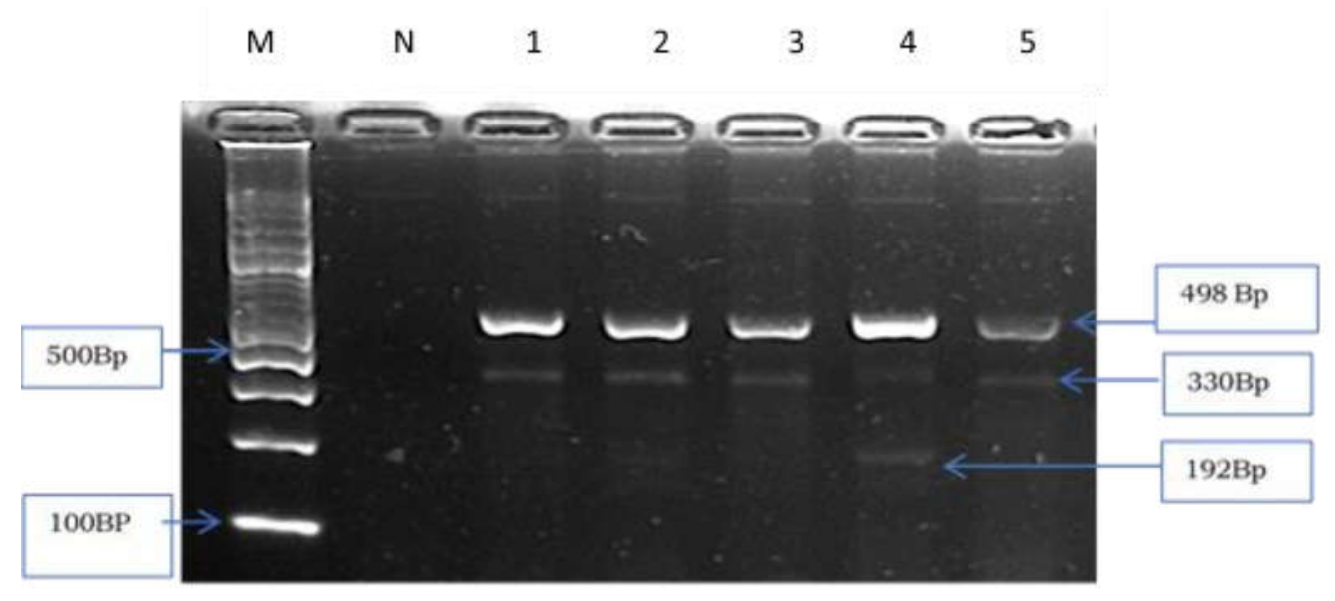

Figure 1. Electrophoresis of multiplex PCR products for sample No. 3 (triple infection) in multiplex method with three primers and annealing temperatures at $50^{\circ} \mathrm{C}$ (lane 1), $51^{\circ} \mathrm{C}$ (lane 2), $52^{\circ} \mathrm{C}$ (lane 3), $53^{\circ} \mathrm{C}$ (lane 4), $54^{\circ} \mathrm{C}$ (lane 5). M:Marker; N:Negative control; PCR product at $498 \mathrm{Bp}$ showed Tricuris trichiura, $330 \mathrm{Bp}$ showed Necator americanus, 192 Bp showed Ascaris lumbricoides. 


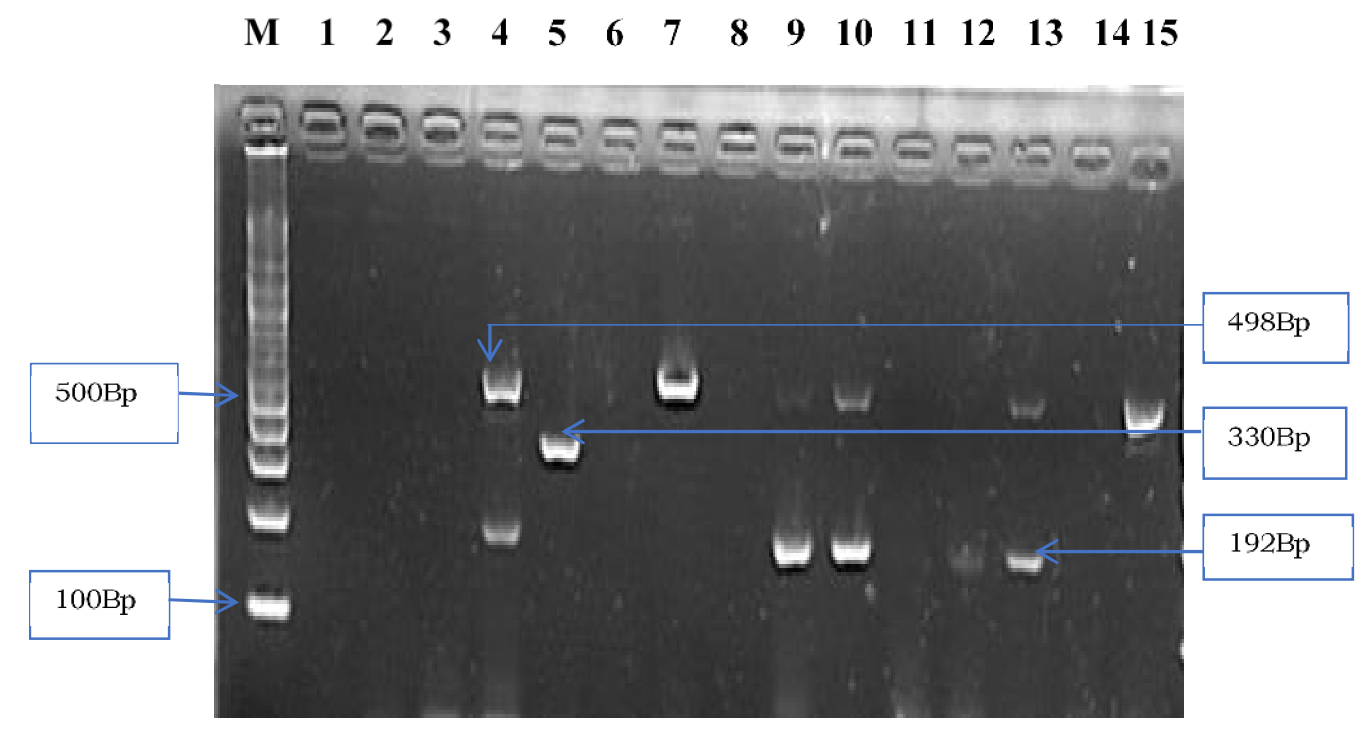

Figure 2. Electrophoresis of multiplex PCR product for samples 1-15. The volume sample $5 \mathrm{mg}$, and $2 \mu \mathrm{LNA}$ template for PCR mixture, with annealing temperature at $53^{\circ} \mathrm{C}$. PCR product at $498 \mathrm{Bp}$ showed Tricuris trichiura, $330 \mathrm{Bp}$ showed Necator americanus, 192 Bp showed Ascaris lumbricoides. marker (M), sample 1 (lane 1), sample 2 (lane 2), and sample 3 (lane 3). Sample 4 (lane 4) shows PCR product at 192 $\mathrm{Bp}$ and $498 \mathrm{Bp}$, sample 5 (lane 5) at $330 \mathrm{Bp}$, sample 6 (lane 6), sample 7 (lane 7) PCR product at $498 \mathrm{Bp}$, sample 8 (lane 8), sample 9 (lane 9) and sample 10 (lane 10) PCR product at $192 \mathrm{Bp}$ and $498 \mathrm{Bp}$, sample 11 (lane 11), sample 12 (lane 12) at $192 \mathrm{Bp}$, sample 13 (lane 13) at $192 \mathrm{Bp}$ and $498 \mathrm{Bp}$, sample 14 (lane 14), sample 15 (lane 15) $\mathrm{PCR}$ product at $498 \mathrm{Bp}$.

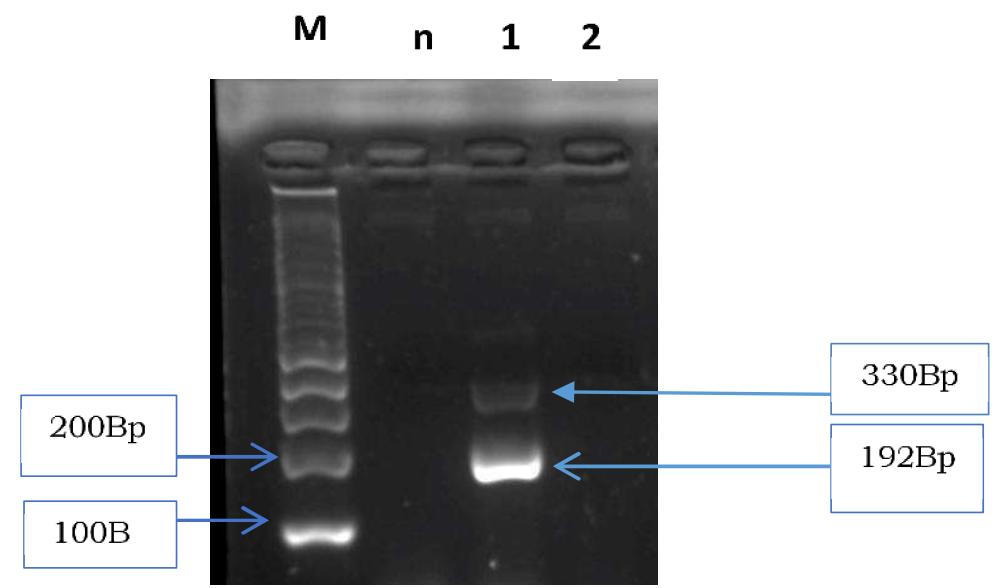

Figure 3. PCR Electrophoresis of PCR product for sample number 5 and 14 , with sample volume $50 \mathrm{mg}$, a template volume $5 \mu \mathrm{l}$ for PCR mixture, and annealing temperature at $53^{\circ} \mathrm{C}$. PCR product at $330 \mathrm{Bp}$ shows the Necator americanus, $192 \mathrm{Bp}$ shows Ascaris lumbricoides. markers (M), negative controls (n), sample 5 (lane 1) PCR product at $192 \mathrm{Bp}$ and $330 \mathrm{Bp}$, samples 14 (lane 2). 


\section{Pre-Treatment With Liquid Nitrogen And Bead-Beating Homogenisation}

Figure 2 to 5 demonstrates the multiplex PCR results of different pretreatment at the optimal annealing temperature. Figure 2 shows result from generic DNA isolation without any pre-treatment, where Trichuris trichiura positive in 6 samples (No 4, 7, 9, 10, 13 and 15), Necator americanus positive in 1 sample (No $5)$, and Ascaris lumbricoides positive in 5 samples (No 4, 9, 10, 12 and 13). Figure 3 shows the result from sample 5 and 14 which underwent pre-treatment with bead-beating homogenisation, where only one sample yielded a positive result for Necator americanus and Ascaris lumbricoides, although the microscopic examination showed triple infection in both samples. Finally, Figure 4 and 5 show the result of pre-treatment with beadbeating homogenisation and liquid nitrogen for all specimen. The comparison of positive results between microscopic examination and the optimised multiplex PCR is shown in Table 3 and 4. Using the microscopic examination as the gold standard, multiplex PCR yield 100\% sensitivity and $50 \%$ specificity for $A$. lumbricoides detection, $46.7 \%$ sensitivity for $T$. trichiura detection, and $66.7 \%$ sensitivity and $22.2 \%$ specificity for $N$. americanus detection (Table 4).

\section{Optimal DNA Concentration}

One sample is selected for examining optimal DNA concentration, where initial concentration was $14.7 \mathrm{ng} / \mu \mathrm{l}$. Figure 6 displays the electrophoresis result of each dilution, where the positive results visible on the 4th dilution for all parasites altogether, and further 8th dilution for at least $\mathrm{A}$. Lumbricoides and $\mathrm{T}$. trichiura detection. Therefore, the minimum DNA concentration of $0.98 \mathrm{ng} / \mu \mathrm{L}$ should be fulfiled for optimal detection of three parasites altogether.

Table 3. The result of optimised multiplex PCR on the preserved stool specimens from Maluku Province, Indonesia ( $=15$ ).

\begin{tabular}{cccc}
\hline ID & & Type of parasite & \\
\cline { 2 - 4 } & Ascaris lumbricoides & Trichuris trichiura & Necator americanus \\
\hline 1 & Positive & Negative & Positive \\
2 & Positive & Negative & Positive \\
3 & Positive & Positive & Positive \\
4 & Positive & Negative & Positive \\
5 & Positive & Negative & Negative \\
6 & Positive & Negative & Negative \\
7 & Positive & Positive & Positive \\
8 & Negative & Positive & Positive \\
9 & Positive & Positive & Positive \\
10 & Positive & Positive & Positive \\
11 & Positive & Negative & Positive \\
12 & Positive & Negative & Negative \\
13 & Positive & Positive & Positive \\
14 & Positive & Negative & Positive \\
15 & Positive & Positive & Negative \\
\hline
\end{tabular}




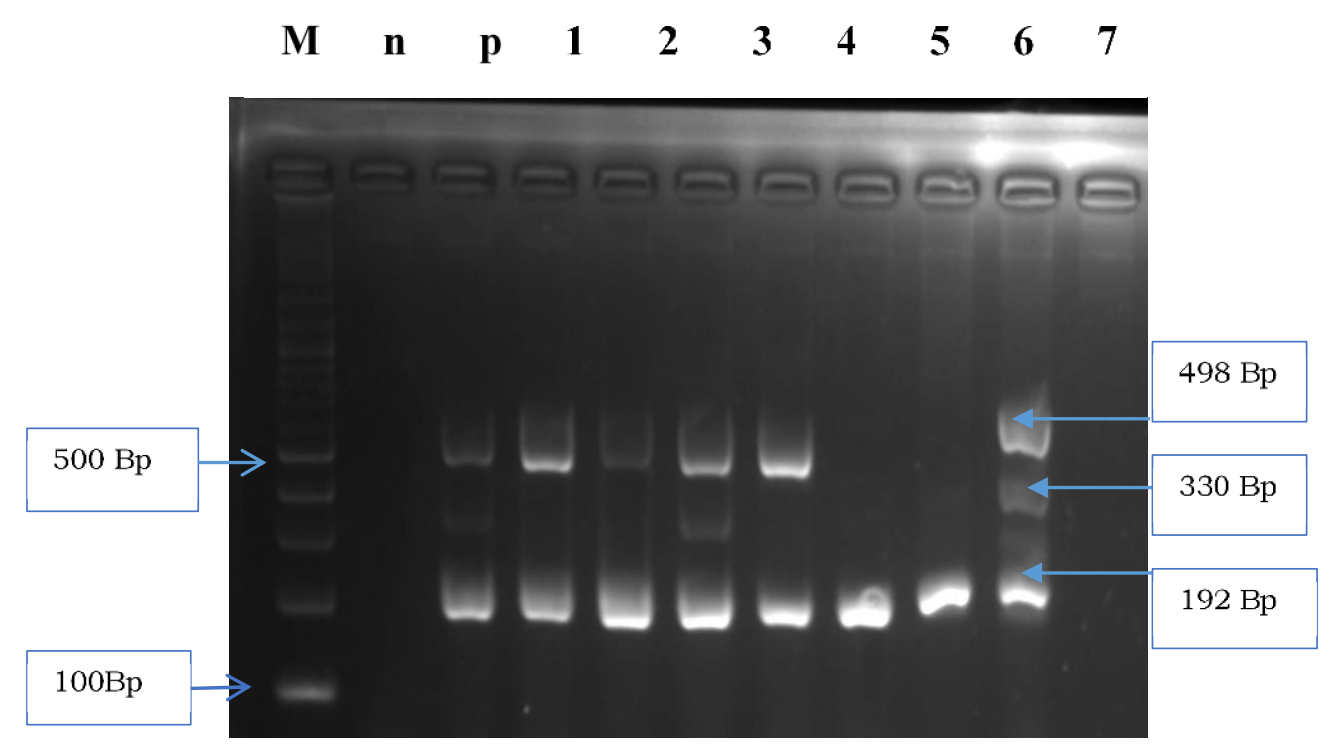

Figure 4a. Electrophoresis PCR product from samples 1-7, volume for DNA isolation $200 \mathrm{mg}$, DNA template volume $5 \mu \mathrm{l}$, annealing temperature at $53^{\circ} \mathrm{C}$, Homogenization with beat beater and liquid Nitrogen before DNA isolation. PCR product at $498 \mathrm{Bp}$ showed Tricuris trichiura, $330 \mathrm{Bp}$ showed Necator americanus, 192 Bp showed Ascaris lumbricoides. marker(M), negative control (n), positive control (p), sample 1 (lane 1) and sample 2 (lane 2) appears band at $192 \mathrm{Bp}$ and $498 \mathrm{Bp}$, sample 3 (lane 3) appears band at $192 \mathrm{Bp}, 330 \mathrm{Bp}$ and $498 \mathrm{Bp}$, sample 4 (lane 4) at $192 \mathrm{Bp}$ and $498 \mathrm{Bp}$, sample 5 (lane 5) and sample 6 (lane 6) band at $192 \mathrm{Bp}$, sample 7 (lane 7) band at $192 \mathrm{Bp}, 330 \mathrm{Bp}$ and $498 \mathrm{Bp}$.

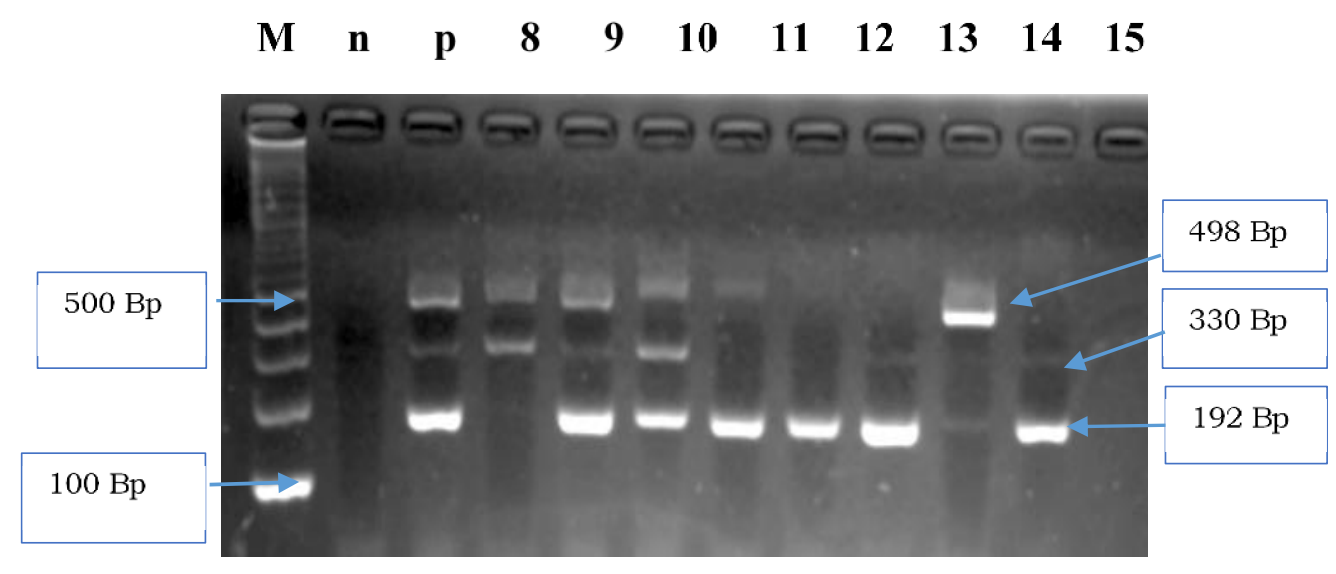

Figure 4b. Electrophoresis PCR products from sample 8-15 with a volume sample for DNA isolation $200 \mathrm{mg}, 5 \mu \mathrm{l}$ volume of template DNA, annealing temperature at $53^{\circ} \mathrm{C}$ and homogenization with beat beater and liquid Nitrogen rapidly before DNA isolation. PCR product at $498 \mathrm{Bp}$ showed Tricuris trichiura, at $330 \mathrm{Bp}$ showed Necator americanus, at $192 \mathrm{Bp}$ showed Ascaris lumbricoides. marker (M), negative control (n), positive control (p), sample 8 (lane 8) shows bands at $330 \mathrm{Bp}$ and $498 \mathrm{Bp}$, samples 9 and 10 appear (lane 9, lane 10) bands at $192 \mathrm{Bp}, 330 \mathrm{Bp}$ and $498 \mathrm{Bp}$, sample 11 (lane 11) looked band at $192 \mathrm{Bp}$ and $498 \mathrm{Bp}$, sample 12 (lane 12) looked band at $192 \mathrm{Bp}$, sample 13 (lane 13) looked band at $192 \mathrm{Bp}$ and 330 $\mathrm{Bp}$, samples 14 (lane 14 ) appeared band at $192 \mathrm{Bp}$ and $498 \mathrm{Bp}$, samples 15 (lane 15) looked 192 Bp and 330 Bp. 
Table 4. The comparison of microscopic examination and optimised multiplex PCR on the preserved stool specimens from Maluku Province, Indonesia ( $\mathbf{n}=15)$.

\begin{tabular}{clcc}
\hline \multirow{2}{*}{ Type of parasite } & \multicolumn{1}{c}{$\begin{array}{c}\text { Microscopic } \\
\text { examination }\end{array}$} & \multicolumn{2}{c}{ Multiplex PCR } \\
\cline { 3 - 4 } Ascaris lumbricoides & Positive & 13 & Negative \\
\cline { 2 - 3 } Trichuris trichiura & Negative & 1 & 0 \\
\multirow{2}{*}{ Necator americanus } & Positive & 7 & 8 \\
& Negative & 0 & 0 \\
& Positive & 4 & 2 \\
& Negative & 7 & 2 \\
\hline
\end{tabular}

\section{DISCUSSION}

This laboratory study has described the role of optimised multiplex PCR to diagnose STH infections compared to the microscopic examination. Using preserved stool samples might yield a different result with fresh stools, yet it is favourable for PCR examination in Indonesia, where the laboratory facility is limited in certain cities while the infection is spread throughout the country.

Based on our results, there are several findings on the optimal condition to produce an accurate PCR diagnosis, which are annealing temperature, volume of DNA template, the pre-treatment, and minimum DNA concentration. The optimal annealing temperature in this research $\left(53^{\circ} \mathrm{C}\right)$ is similar with the previous study with a similar setting in Thailand specimens. ${ }^{9}$ Increasing sample weight and DNA template volume should theoretically improve accuracy. Although there was a decreased detection rate when we add the sample up to $30 \mathrm{mg}$ and the DNA template to $5 \mu \mathrm{l}$, we could reach an optimal result with $200 \mathrm{mg}$ sample and $5 \mu \mathrm{l}$ DNA template. Higher content of the specimen might increase the possibility of finding positive results.

Pre-treatment before DNA isolation procedure with bead-beating homogenisation and liquid nitrogen apparently improved the accuracy. These treatments are supposedly increasing concentration of DNA extracted, by freezing the cell wall, while cleansing the specimen from any substances which could interfere with the DNA amplification. 10,11

Despite the optimal condition for multiplex PCR testing, our result on $T$. trichiura detection was quite low compared to the microscopic examination. Isolation of $T$. trichiura DNA from eggs was difficult due to its sturdy, which might need a longer time to homogenise, heated and centrifugation. ${ }^{10}$ Other plausible explanation would be related to the long-term preservation, which conserve the cell wall, except its genetic material. We observed some 'empty' Trichuris egg in microscopic examination hence categorised them as positive case. In some cases, the positive microscopic examination might be explained by the possibility of $T$. vulpis infection resembling the $T$. trichiura morphology, but with different genetic material, thus resulted in negative PCR tests. ${ }^{12}$

This study has also determined the minimum DNA concentration of $0.98 \mathrm{ng} / \mu \mathrm{l}$. Previous research found a more sensitive threshold of 0.001 $\mathrm{ng} / \mu \mathrm{l} .{ }^{13}$ However, this sensitivity might be influenced by difference PCR components mixture and facilities.

\section{CONCLUSIONS}

Multiplex PCR could be used to diagnose STH infections from the preserved faecal specimen with various detection rate compared to microscopic examination. The optimal settings are (a) annealing 
temperature at $53^{\circ} \mathrm{C}$, (b) sample weight $200 \mathrm{mg}$ and DNA template volume $5 \mu \mathrm{l}$, (c) pre-treatment with bead-beating homogenisation and liquid nitrogen prior to DNA isolation, and (d) minimum DNA concentration of $0.98 \mathrm{ng} / \mu \mathrm{l}$. Future studies might need to explore other methods to achieve optimal DNA isolation and amplification, especially for $T$. trichiura infection and shorter period of stool specimen preservation. Besides, T. trichiura diagnosis with multiplex PCR must be interpreted cautiously with the corresponding microscopic examination to give accurate results.

\section{ACKNOWLEDGEMENTS}

The author would like to thank Mr. Martinus Vinsensius Dhona as a previous researcher who permitted to use the samples collected in his research as samples tested in this study.

\section{REFERENCES}

1. Soil-transmitted helminth infections [Internet]. [accessed on 20 November 2017]. Available

at: https://www.who.int/newsroom/fact-sheets/detail/soiltransmitted-helminth-infections

2. Dunn JC, Turner HC, Tun A, Anderson RM. Epidemiological surveys of, and research on, soiltransmitted helminths in Southeast Asia: a systematic review. Parasit Vectors. 27 January 2016;9(1):31.

3. Direktorat Jenderal Pengendalian dan Penyehatan Lingkungan Kementerian Kesehatan RI. Rencana Aksi Program Pengendalian dan Penyehatan Lingkungan Tahun 2015-2019. Decree No. HK. 02.03/D1/I.1/2088/2015.

4. Khurana S, Sethi S. Laboratory diagnosis of soil transmitted helminthiasis. Trop Parasitol. 7 January 2017;7(2):86.

5. Zhang $\mathrm{H}$, Morrison S, Tang $\mathrm{Y}-\mathrm{W}$. Multiplex PCR Tests for Detection of Pathogens Associated with
Gastroenteritis. Clin Lab Med. June 2015;35(2):461-86.

6. Soonawala $\mathrm{D}$, van Lieshout $\mathrm{L}$, den Boer MAM, Claas ECJ, Verweij JJ, Godkewitsch A, dkk. Post-Travel Screening of Asymptomatic LongTerm Travelers to the Tropics for Intestinal Parasites Using Molecular Diagnostics. Am J Trop Med Hyg. 7 May 2014;90(5):835-9.

7. Lorenz TC. Polymerase Chain Reaction: Basic Protocol Plus Troubleshooting and Optimization Strategies. J Vis Exp JoVE. 22 May 2012;63:e3998.

8. Lamberton PHL, Jourdan PM. Human Ascariasis: Diagnostics Update. Curr Trop Med Rep. 1 December 2015;2(4):189-200.

9. Phuphisut $\mathrm{O}$, Yoonuan $\mathrm{T}$, Sanguankiat S, Chaisiri K, Maipanich W, Pubampen S, dkk. Triplex polymerase chain reaction assay for detection of major soiltransmitted helminths, Ascaris lumbricoides, Trichuris trichiura, Necator americanus, in fecal samples. Southeast Asian J Trop Med Public Health. March 2014;45(2):267-75.

10. Verweij JJ, Stensvold CR. Molecular Testing for Clinical Diagnosis and Epidemiological Investigations of Intestinal Parasitic Infections. Clin Microbiol Rev. April 2014;27(2):371418.

11. Kaisar MMM, Brienen EAT, Djuardi $\mathrm{Y}$, Sartono E, Yazdanbakhsh M, Verweij JJ, et al. Improved diagnosis of Trichuris trichiura by using a bead-beating procedure on ethanol preserved stool samples prior to DNA isolation and the performance of multiplex real-time PCR for intestinal parasites. Parasitology. June 2017;144(7):965-74.

12. Márquez-Navarro A, GarcíaBracamontes G, Álvarez-Fernández BE, Ávila-Caballero LP, SantosAranda I, Diaz-Chiguer DL, et al. Trichuris vulpis (Froelich, 1789) Infection in a Child: A Case Report. Korean J Parasitol. 6 March 2012;50(1):69-71.

13. Sanprasert V, Kerdkaew R, Srirungruang S, Charuchaibovorn S, Phadungsaksawasdi
$\mathrm{K}$, 
Nuchprayoon S. Development of Conventional Multiplex PCR: A Rapid Technique for Simultaneous
Detection of Soil-Transmitted Helminths. Pathogens. 16 September 2019;8(3): 152 . 